\title{
Neonatal Exposure to 17a-Ethinyl Estradiol Affects Kisspeptin Expression and LH- Surge Level in Female Rats
}

\author{
Kento USUDA ${ }^{1)}$, Kentaro NAGAOKA ${ }^{1) *}$, Kaori NOZAWA ${ }^{1)}$, Haolin ZHANG $^{1)}$, Kazuyoshi TAYA ${ }^{1)}$, Midori YOSHIDA ${ }^{2)}$ \\ and Gen WATANABE ${ }^{1)}$ \\ 1) Laboratory of Veterinary Physiology, Department of Veterinary Medicine, Tokyo University of Agriculture and Technology, 3-5-8 \\ Saiwai-cho, Fuchu-shi, Tokyo 183-8509, Japan \\ 2) Division of Pathology, National Institute of Health Sciences, 1-18-1 Kamiyoga, Setagaya-ku, Tokyo 158-8501, Japan
}

(Received 19 March 2014/Accepted 11 April 2014/Published online in J-STAGE 1 May 2014)

ABSTRACT. Contamination of estrogenic compounds disrupts endocrinological and neurological reproductive systems in animals. Neonatal exposure to $17 \alpha$-ethinyl estradiol (EE) induced an abnormal estrous cycle at postnatal day (PND) 180, but not at PND90. We found that serum level of luteinizing hormone (LH) at the latter half of proestrus in EE-treated rats was lower than in the controls at PND90 when there was no significant difference on estrous cyclicity. Additionally, kiss 1 mRNA levels in the anteroventral periventricular nucleus-preoptic area (AVPV/POA) were lower in EE-treated rats than in the controls. The expression of GnRH precursor (GNRH1) mRNA in the AVPV/ POA and that of LH beta subunit $(L H b)$ mRNA in the pituitary were similar in the control- and EE-treated groups. Our results indicated that neonatal exposure to EE leads to reduced expression of kiss 1 mRNA in AVPV/POA and LH-surge, which is likely related to the delayed reproductive dysfunction seen in adult female rats.

KEY WORDS: $17 \alpha$-ethinyl estradiol, AVPV/POA, endocrine disruptor, kisspeptin

doi: 10.1292/jvms.14-0148; J. Vet. Med. Sci. 76(8): 1105-1110, 2014

It has been approximately 20 years since the first World Wildlife Federation (WWF) Wingspread Conference focused on endocrine-disrupting chemicals (EDCs) [11]. EDCs are a broad class of synthetic and natural chemicals, most of which have estrogenic activity [11]. Because these chemicals mimic estrogens that regulate cell fate during embryonic development, exposure to these compounds during the fetal and perinatal periods leads to disruption of endocrinological, neurological and reproductive functions [24].

In rodents, the sexual differentiation of the brain occurs during the late embryonic and early postnatal periods [14]. In males, androgen secreted from the testis passes the Blood-Brain-Barrier (B-B-B) and reaches the brain, where it is converted to estradiol by the action of $\mathrm{p} 450$ aromatase enzymes [10]. The estradiol is essential for the normal sexual differentiation of the male brain. In females, the developing ovary secretes estradiol, but most of the circulating estradiol remains bound to $\alpha$-fetoprotein and cannot pass the B-B-B [21]. Synthetic estrogenic compounds show the ability to escape from binding to $\alpha$-fetoprotein. Therefore, exposure to synthetic estrogen compounds during the perinatal period may affect the sexual differentiation of the brain in female rodents.

Kisspeptin, a neuropeptide, plays key roles in determining

\footnotetext{
*Correspondence to: Nagaoka, K., Laboratory of Veterinary Physiology, Department of Veterinary Medicine, Tokyo University of Agriculture and Technology, 3-5-8 Saiwai-cho, Fuchu-shi, Tokyo 183-8509, Japan. e-mail: nagaokak@cc.tuat.ac.jp

(C)2014 The Japanese Society of Veterinary Science

This is an open-access article distributed under the terms of the Creative Commons Attribution Non-Commercial No Derivatives (by-nc-nd) License $<$ http://creativecommons.org/licenses/by-nc-nd/3.0/>.
}

the timing of puberty and regulation of the estrous cycle by stimulating the Hypothalamic-Pituitary-Gonadal axis (HPG axis) [15]. Kisspeptin is expressed in the anteroventral periventricular nucleus (AVPV) and the arcuate nucleus (ARC) [27]. The number of kisspeptin neurons in the AVPV is substantially higher in females than in males, but their numbers in the ARC are not sexually dimorphic [2]. In female mice, the number of the kisspeptin neurons in the AVPV increases after birth and reaches adult levels at the time of puberty [4]. Because kisspeptin neurons express estrogen receptor $\alpha$ $(\mathrm{ER} \alpha)$, it is thought that the increase in the number of kisspeptin neurons is regulated by estradiol secreted from the developing ovary. Conditional deletion of $\mathrm{ER} \alpha$ from kisspeptin neurons resulted in an arrest in the pubertal maturation and a failure to acquire normal estrous cycle [20].

Kisspeptin acts through binding to the $\mathrm{G}$ protein-coupled receptor GPR54 [15]. This receptor is expressed in $\mathrm{GnRH}$ neurons, which are primarily located in the preoptic area (POA) and the ARC $[15,17]$. Kisspeptin bound to the receptor in POA induces a GnRH-surge followed by an LHsurge [9]. Kisspeptin bound to its receptor in ARC controls the GnRH and LH pulses $[17,18]$. Studies have shown that EDCs cause reproductive dysfunction by affecting the population of kisspeptin neurons [7, 26]. However, the effects of EDCs on kisspeptin neurons remain largely uncharacterized.

In this study, we used $17 \alpha$-ethinyl estradiol (EE) as model EDC. Previous studies found that a one-time administration of EE $(20 \mu \mathrm{g} / \mathrm{kg})$ at postnatal day 1 (PND1) induced abnormal estrous cycle during PND171-190 [22]. To identify the potential changes in kisspeptin neuron following neonatal exposure to EE, we determined the serum levels of reproductive hormones and analyzed the gene expression in AVPV/ POA, ARC and pituitary at PND90 before the appearance 
of the abnormal estrous cycle. Here, we show that neonatal EE exposure leads to a reduction in LH-surge and reduced expression of kisspeptin in AVPV/POA.

\section{MATERIALS AND METHODS}

Animals: Adult Wistar-Imamichi rats were maintained in an animal room under standard housing conditions with controlled lighting (lights on from $05 \mathrm{hr} 00$ to $19 \mathrm{hr} 00$ ), temperature $\left(25 \pm 2^{\circ} \mathrm{C}\right)$ and humidity $(50 \pm 10 \%)$. Animals were provided with a rat chow diet (MR-Breeder, Nosan Corporation, Yokohama, Japan) and tap water ad libitum. All animal experiments were performed in compliance with the guidelines of the Institutional Animal Care and Use Committee of Tokyo University of Agriculture and Technology, Japan.

Experimental design: Figure 1 illustrates the experimental design. The sex ratio of the newborn pups in each litter was adjusted to $6: 3$ (females: males). Female pups were given one of the following neonatal treatments: 1) sesame oil vehicle alone (control group), 2) EE at $20 \mu \mathrm{g} / \mathrm{kg}$ and 3) $\mathrm{EE}$ at $200 \mu \mathrm{g} / \mathrm{kg}$. These treatments were administered within 24 hr of delivery, on PND0, by subcutaneous (S.C.) injection in the nape of the neck. Once vaginal opening occurred, a daily vaginal smear was collected from each rat and the cytological changes were monitored until PND90 (n=16 for each treatment). At approximately PND90, pups were euthanized at $11 \mathrm{hr} 00$ on the second diestrous day (D), at $11 \mathrm{hr} 00 \mathrm{on}$ the proestrous day (PE11), at $17 \mathrm{hr} 00$ on the proestrous day (PE17) and at $11 \mathrm{hr} 00$ on the estrous day (E), and the blood and brains were collected $(n=4$ for each time point). The blood samples were immediately centrifuged $(1,500 \times g$ for $15 \mathrm{~min}$ at $4^{\circ} \mathrm{C}$ ), and the serum was stored at $-20^{\circ} \mathrm{C}$ until use. The AVPV/POA, the ARC and the pituitary were dissected out from the brain, snap frozen in liquid nitrogen and stored $-80^{\circ} \mathrm{C}$ until further use in RNA extraction. The AVPV/POA and the ARC regions were punched out with the help of a brain punch set (inner diameter of $1.0 \mathrm{~mm}$; Stoeling Corporation., Wheat Lane, Wood Dale, IL, U.S.A. [12]) from the coronal section of the brain following the coordinates provided in the brain atlas (Paxinos and Watson atlas) [16].

Hormone assay: Serum concentrations of $\mathrm{LH}$, follicle stimulating hormone (FSH) and prolactin were measured using a rat radioimmunoassay (RIA) kit (NIH, Bethesda, MD, U.S.A.). The iodinated preparations used were rat LH-I-7, rat FSH-I-7 and PRL-I-6. The antisera used were anti-rat LH-S10, anti-rat FSH-S-11 and PRL-S-9, respectively. The results were expressed in terms of NIDDK rat LH-RP-3, FSH-RP-2 and PRL-RP3. The intra- and inter-assay coefficients of variations were; $2.7 \%$ and $22.08 \% ; 7.1 \%$ and $22.75 \%$; and $2.46 \%$ and $22.20 \%$ for LH, FSH and prolactin, respectively.

The serum concentrations of immunoreactive (ir-) inhibin were measured using the rabbit antiserum against bovine inhibin (TNDH-1) and the ${ }^{125} \mathrm{I}$-labeled 32-kDa bovine inhibin. Results were expressed as the concentrations of $32-\mathrm{kDa}$ bovine inhibin. The intra- and inter-assay coefficients of variation were $4.77 \%$ and $10.30 \%$, respectively.

The serum concentrations of estradiol and testosterone were measured with the help of a double-antibody RIA system using ${ }^{125} \mathrm{I}$-labeled radio ligands. Antisera against estradiol (GDN \#244) and testosterone (GDN \#250) were provided by Dr. G. D. Niswender (Animal Reproduction and Biotechnology, Colorado State University, Fort Collins, CO, U.S.A.). The intra- and inter-assay coefficients of variation were $5.47 \%$ and $18.40 \%$, respectively for estradiol and $2.89 \%$ and $21.28 \%$, respectively for testosterone.

Quantitative real-time PCR: Total RNA from each sample was extracted using ISOGEN (Nippon Gene, Tokyo, Japan). Complementary DNA (cDNA) was synthesized using PrimeScript reverse transcriptase (TaKaRa Bio, Otsu, Japan) according to the manufacturer's instructions. Oligonucleotide primers were designed using the web-based Primer3 software and are listed in Supplementary Table 1. All polymerase chain reactions were performed using SYBR Premix Ex Taq ${ }^{\mathrm{TM}}$ (TaKaRa Bio). The relative expression level of each target mRNA was determined using the $2^{-\Delta \Delta \mathrm{CT}}$ method. $G A P D H$ or $\beta$-Actin was used as the endogenous control gene.

Statistical analysis: The data are presented as the mean \pm SEM of values from three independent experiments. The level of significance was analyzed using one-way analysis of variance (ANOVA), followed by multiple range tests (Graph Pad Prism5). Differences with $P<0.05$ were considered statistically significant.

\section{RESULTS}

Effect of neonatal EE exposure on reproductive parameters: The changes in body weights are shown in Fig. 2a. The rats in all treatment groups grew normally, and there was no significant difference between the body weights of control and EE-treated groups. The timing of the vaginal opening, which is indicative of puberty, is compared between control and EE-treated groups in Fig. 2b. There was no significant difference between the timing of vaginal opening of the control and EE-treated groups. The time spent in each cycle day at PND90 is shown in Fig. 2c. There was no significant difference in the estrous cycles of all groups at PND90.

Effect of neonatal EE exposure on hormonal changes at PND90: The changes in the serum levels of LH, FSH, inhibin, prolactin, estradiol and testosterone are shown in Fig. 3. LH-surge was observed at PE17, and the peak levels were reduced in the EE-treated groups compared to control group. In $200 \mu \mathrm{g} / \mathrm{kg}$ EE-treated group, increases of FSH at diestrous and testosterone at PE11 were observed (Fig. 3b and $3 \mathrm{e})$. There were no significant differences in the levels of other hormones between control and EE-treated groups.

Effect of neonatal EE exposure on hypothalamic gene expression at PND90: To examine the potential hypothalamic changes in EE-treated animals, the kisspeptin (kiss 1), GPR54, ER $\alpha$ and GNRH1 mRNA levels in the AVPV/POA and the ARC regions were quantified by quantitative realtime PCR. EE treatment reduced the levels of kiss 1 mRNA in the AVPV/POA at PE17 (Fig. 4a). In $200 \mu \mathrm{g} / \mathrm{kg}$ EE-treated group, decrease of GNRH1 mRNA expression at diestrous was observed (Fig. 4d). There were no significant differences in the mRNA levels of GPR54 and ER (Fig. 4b and 


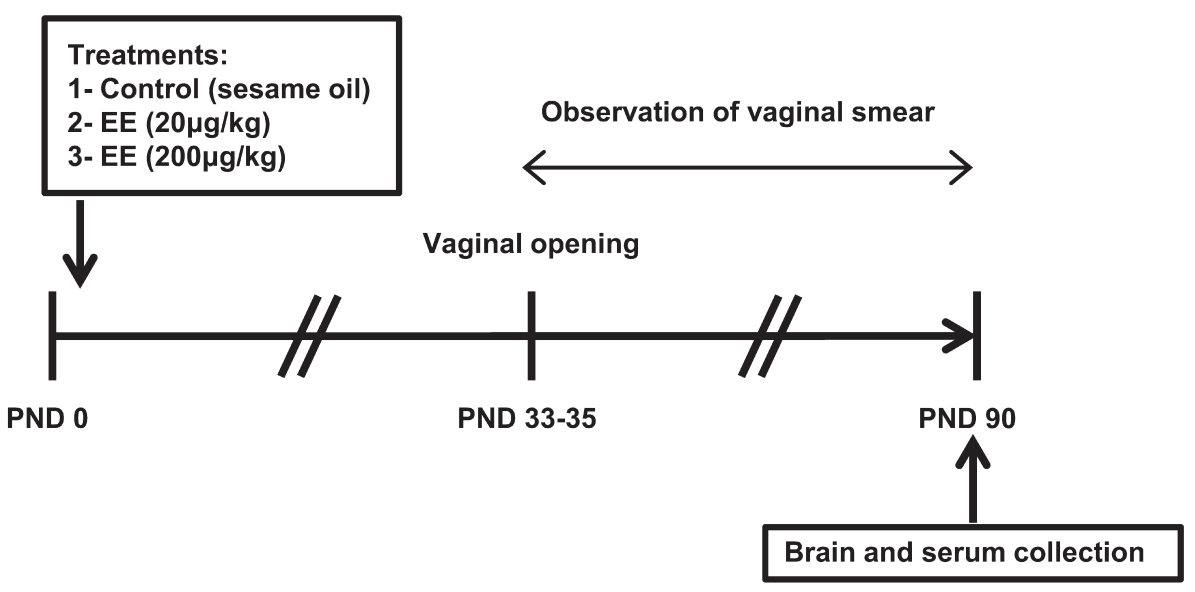

Fig. 1. Schematic representation of experimental protocol. PND, postnatal day.

a

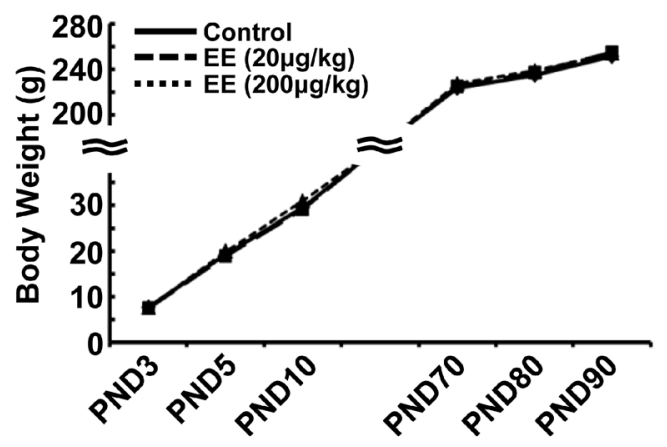

b

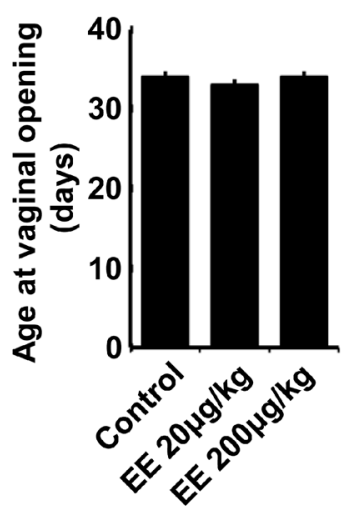

C

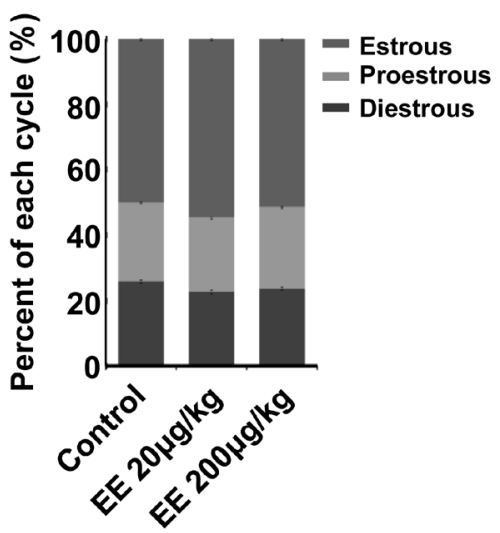

Fig. 2. Effect of neonatal EE exposure on body weight and reproductive parameters. (a) Body weight from PND3 to PND10 and from PND70 to PND90. PND, postnatal day. (b) Age at vaginal opening. (c) Percent of time spent in each cycle day during PND75-90. Rats were neonatally treated with sesame oil and with 2 concentrations of EE $(20 \mu \mathrm{g} / \mathrm{kg}$ and $200 \mu \mathrm{g} / \mathrm{kg})$. Estrous stage was determined by vaginal cytology. Data are presented as the mean \pm SEM.

4c). Compared to controls, the expression of kiss 1 mRNA in the ARC of $200 \mu \mathrm{g} / \mathrm{kg}$ EE-treated group was lower at PE17 (Fig. 5a). However, there were no significant differences in the mRNA levels of GPR54, ER $\alpha$ and GNRH1 between the ARCs of control and EE-treated groups (Fig. 5b, 5c and 5d).

Effect of neonatal EE exposure on pituitary gene expression at PND90: The mRNA levels of $L H b$, FSH beta subunit $(F S H b)$, prolactin $(P R L)$ and GnRH receptor $(G N R H R)$ were determined by quantitative real-time PCR (Fig. 6). There were no significant differences in the mRNA expression levels of other genes between the control and the treatment groups.

\section{DISCUSSION}

It has been reported that the perinatal exposure to EDCs affects the HPG axis and the brain development related to sexual differentiation. Here, we report EE-induced changes that are potentially related to the delayed reproductive dysfunction. Neonatal EE exposure caused a reduction in the LH-surge level at PND90 when the animals showed a normal estrous cycle. In contrast, these animals showed abnormal estrous cycle at PND180. Reduced kiss 1 mRNA expression was also observed in the AVPV/POA of EE-treated animals. It has been reported that in males, no LH-surge occurred and the expression level of kisspeptin in the AVPV/POA was lower in males than females [1,2]. Neonatal exposure of neonatal females to EE might induce the masculinization of the AVPV/POA region during the sexual differentiation of the brain, which is likely the reason for the reduced kisspeptin gene expression and the low LH-surge at PND90.

In this study, we administered EE (20 and $200 \mu \mathrm{g} / \mathrm{kg}$ ) to pups subcutaneously at PND0. The EE has been widely used for oral contraception in women, and the pills contain 50 $\mu \mathrm{g}$ EE, corresponding to $1.0 \mu \mathrm{g} / \mathrm{kg} /$ day. The doses selected in this study were approximately 20-200 times higher than 
a

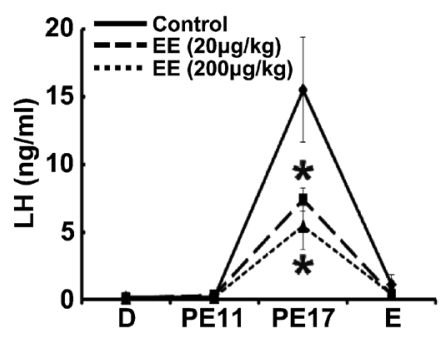

d

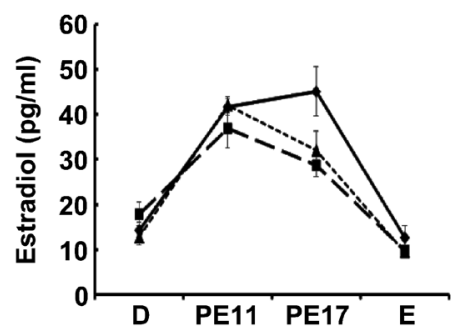

b

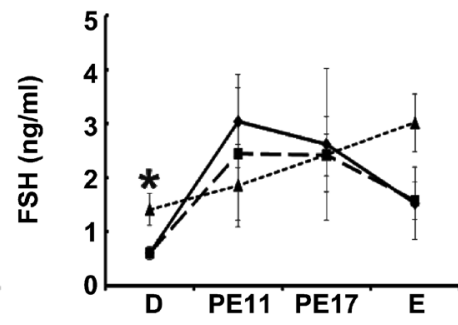

e

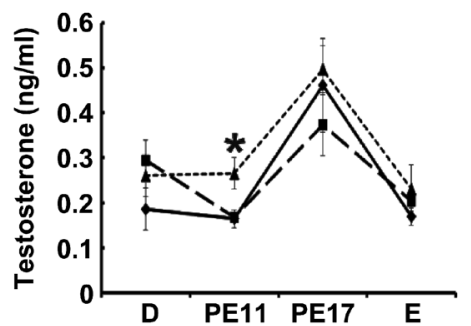

C

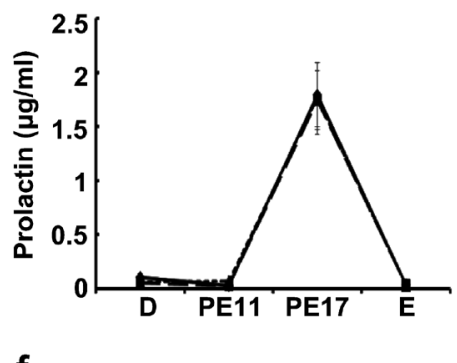

f

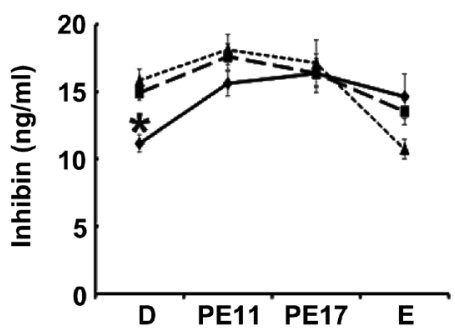

Fig. 3. Changes in serum level of LH (a), FSH (b), prolactin (c), estradiol-17ß (d), testosterone (e) and inhibin (f) in neonatal EE treated rats. Bloods were collected at PND90 from animals treated with sesame oil and with 2 concentrations of EE $(20 \mu \mathrm{g} / \mathrm{kg}$ and $200 \mu \mathrm{g} / \mathrm{kg})$. Hormone level was measured by RIA. Each point represents mean \pm SEM. Asterisk indicates a significant difference compared to the control $(P<0.05)$. D, Diestrous PE11, Proestrous at $11 \mathrm{hr} 00$ PE17, Proestrous at $17 \mathrm{hr} 00 \mathrm{E}$, Estrous.

a

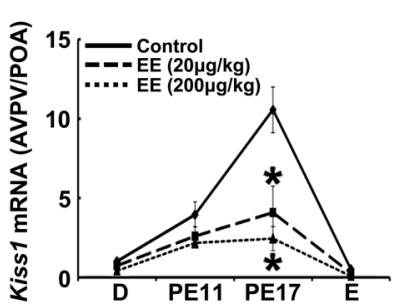

C

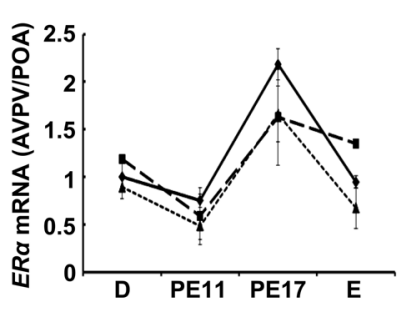

Fig. 4. Changes in kissl(a), GPR54 (b), ERa (c) and GNRH1 (d) mRNA expression in AVPV/POA. Samples were collected at PND90 from animals treated with sesame oil and with two concentrations of EE $(20 \mu \mathrm{g} / \mathrm{kg}$ and $200 \mu \mathrm{g} / \mathrm{kg})$. mRNA expression level was analyzed by real-time PCR. Each point represents mean \pm SEM. Asterisk indicates a significant difference compared to the control $(P<0.05)$. D, Diestrous PE11, Proestrous at $11 \mathrm{hr} 00$ PE17, Proestrous at $17 \mathrm{hr} 00 \mathrm{E}$, Estrous. a

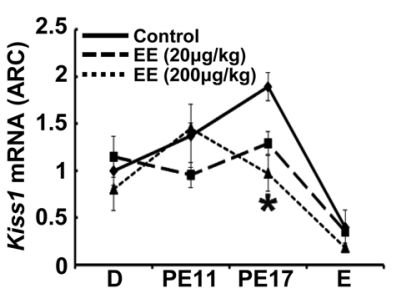

C

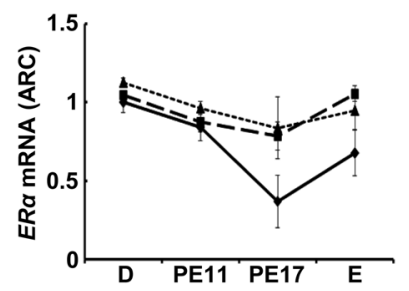

b

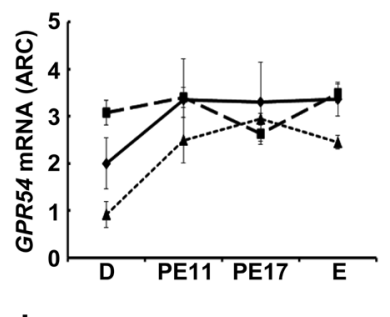

d

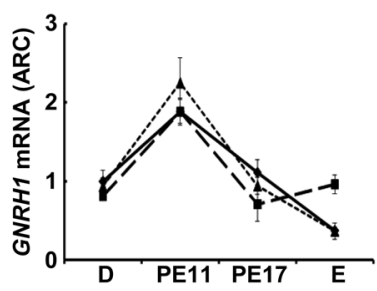

Fig. 5. Changes in kissl(a), GPR54 (b), ERa (c) and GNRH1 (d) mRNA expression in ARC. Samples were collected at PND90 from animals treated with sesame oil and with 2 concentrations of EE $(20 \mu \mathrm{g} / \mathrm{kg}$ and $200 \mu \mathrm{g} / \mathrm{kg})$. mRNA expression level was analyzed by real-time PCR. Each point represents mean \pm SEM. Asterisk indicates a significant difference compared to the control $(P<0.05)$. D, Diestrous PE11, Proestrous at $11 \mathrm{hr} 00$ PE17, Proestrous at 17 hr $00 \mathrm{E}$, Estrous. 

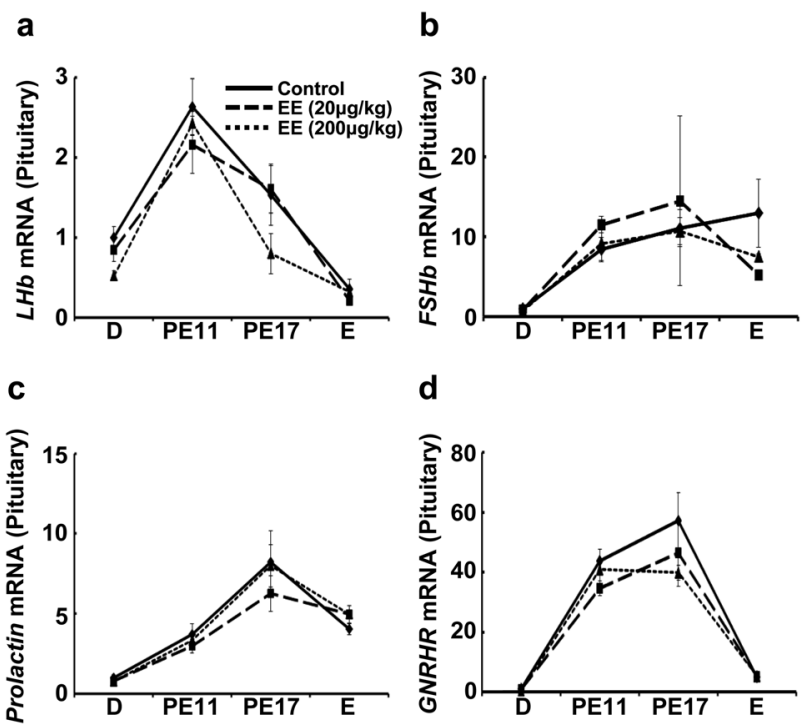

Fig. 6. Changes in $L H b$ (a), FSHb (b), prolactin (c) and GNRHR (d) mRNA expression in pituitary. Samples were collected at PND90 from animals treated with sesame oil and with 2 concentrations of $\mathrm{EE}(20 \mu \mathrm{g} / \mathrm{kg}$ and $200 \mu \mathrm{g} / \mathrm{kg})$. mRNA expression level was analyzed by real-time PCR. Each point represents mean \pm SEM. Asterisk indicates a significant difference compared to the control $(P<0.05)$. D, Diestrous PE11, Proestrous at $11 \mathrm{hr} 00$ PE17, Proestrous at $17 \mathrm{hr}$ 00 E, Estrous.

exposure of women. In a previous study, EE $(5-50 \mu \mathrm{g} / \mathrm{kg} /$ day) was administered to dams by oral gavage from gestational day (GD) 7 to PND22 [18]. The authors reported that there were no changes in the kiss 1 mRNA expression in the AVPV/POA of pups at PND50 [18]. However, the quantity of EE that reached the pup's circulation is not known. The lower chronic exposure was not sufficient to induce changes in kiss 1 gene expression. It is likely that the metabolism of EE in the mother's body, placenta and mammary gland might prevent EE from entering the pup's circulation. Therefore, the timing and method of administration should be prescribed for a comprehensive assessment of the effects of EE.

Estrogen regulates kiss $1 \mathrm{mRNA}$ expression in kisspeptin neurons [15]. Two distinct subtypes of ER, ER $\alpha$ and ER $\beta$, are known [21]. ER $\alpha$ is predominantly expressed in the uterus, mammary gland, testis, pituitary, liver and kidney, whereas $E R \beta$ is primarily expressed in the ovary and prostate [6]. Kisspeptin neurons highly express high levels of ER $\alpha$, which is higher in females than in males [3, 16, 25]. Estrogen fails to stimulate kiss 1 mRNA expression in kisspeptin neurons of the ovariectomized ER $\alpha$-knockout mice [28]. Thus, ER $\alpha$ mediates estrogen-induced kiss 1 gene expression [5]. Our results showed that the expression level of ER $\alpha$ in the AVPV/POA and the ARC of the control- and EE-treated groups was similar. Additionally, serum level of estrogen was unaffected by EE treatment. Taken together, the reduced expression of kiss 1 mRNA in the AVPV/POA of EE-treated animals may have been due to a functional impairment of signaling downstream of ER.
The serum LH-surge levels decreased along with the reduction in the level of kiss 1 mRNA. Generally, kisspeptin controls LH levels through activating GnRH neuron. GnRHsurge released from the AVPV/POA stimulates pituitary gonadotroph to induce LH-surge without stimulating the transcription. GnRH-pulse generated from the ARC controls basal LH and FSH expression. The AVPV/POA and ARC contained GnRH neurons and we investigated the expression levels of GNRH1 and GPR54 mRNA, however, there were no significant differences in both regions. Furthermore, the expression of $L H b$ and $G N R H R$ mRNA remained unchanged in the pituitary. In $200 \mu \mathrm{g} / \mathrm{kg}$ EE-treated group, the serum FSH showed irregular changes during the estrus cycle, but the expression of FSHb mRNA did not change in the pituitary. It was reported that kisspeptin also elicits FSH secretion and intracerebroventricular administration of kisspeptin peptide stimulated FSH secretion in prepubertal and adult rats $[23,27]$. These observations provided the possibility that the decrease in LH-surge and irregular FSH might be linked to the weaken GnRH neuron activity and/or reduced GnRH secretion via down-expressed kisspeptin in the AVPV/POA and ARC of EE-treated animals.

In conclusion, we showed that neonatal exposure to EE leads to reduced kisspeptin expression in the AVPV/ POA and reduced LH-surge, which is likely involved in the delayed reproductive dysfunction in the adult animals. Previous studies have found that when compared to young rats exhibiting normal estrous cycle, middle-aged rats with persistent estrous had low LH-surge and lower percentage of kiss1 mRNA-positive neurons with c-fos immunoreactivity in the AVPV [8, 13, 19, 29]. Since there are some similarities on reproductive phenotypes between neonatal EE exposure animals and middle-aged animals, neonatal EE administration may be useful for generating animal models to investigate the physiological and molecular mechanisms of reproductive aging. Further studies are needed to identify the mechanisms responsible for the suppression of kisspeptin expression following exposure to EE.

ACKNOWLEDGMENT. This study was supported by Health and Labor Sciences Research Grants, Research on Risk of Chemical Substances, Ministry of Health, Labor and Welfare, Japan [H25-Toxicol-003].

\section{REFERENCES}

1. Bai, Y., Chang, F., Zhou, R., Jin, P. P., Matsumoto, H., Sokabe, M. and Chen, L. 2011. Increase of anteroventral periventricular kisspeptin neurons and generation of E2-induced LH-surge systems in male rats exposed perinatally to environmental dose of bisphenol-A. Endocrinology 152: 1562-1571. [Medline] [CrossRef]

2. Bateman, H. L. and Patisaul, H. B. 2008. Disrupted female reproductive physiology following neonatal exposure to phytoestrogens or estrogen specific ligands is associated with decreased $\mathrm{GnRH}$ activation and kisspeptin fiber density in the hypothalamus. Neurotoxicology 29: 988-997. [Medline] [CrossRef]

3. Cao, J. and Patisaul, H. B. 2011. Sexually dimorphic expression of hypothalamic estrogen receptors $\alpha$ and $\beta$ and kiss1 in neonatal 
male and female rats. J. Comp. Neurol. 519: 2954-2977. [Medline] [CrossRef]

4. Clarkson, J. and Herbison, A. E. 2006. Postnatal development of kisspeptin neurons in mouse hypothalamus: Sexual dimorphism and prejections to gonadotropin-releasing hormone neurons. Endocrinology 147: 5817-5825. [Medline] [CrossRef]

5. Clarkson, J., Boon, W. C., Simpson, E. R. and Herbison, A. E. 2009. Postnatal development of an estradiol-kisspeptin positive feedback mechanism implicated in puberty onset. Endocrinology 150: 3214-3220. [Medline] [CrossRef]

6. Couse, J. F. and Korach, K. S. 1999. Estrogen receptor null mice: what have we learned and where will they lead us? Endocr. Rev. 20: 358-417. [Medline] [CrossRef]

7. Dickerson, S. M., Cunningham, S. L., Patisaul, H. B. P., Woller, M. J. and Gore, A. C. 2011. Endocrine disruption of brain sexual differentiation by developmental PCB exposure. Endocrinology 152: 581-594. [Medline] [CrossRef]

8. Downs, J. L. and Wise, P. M. 2009. The role of the brain in female reproductive aging. Mol. Cell. Endocrinol. 299: 32-38. [Medline] [CrossRef]

9. García-Galiano, D., Pinilla, L. and Sempere, M. T. 2012. Sex steroids and the control of the kiss1 system: Developmental roles and major regulatory actions. J. Neuroendocrinol. 24: 22-33. [Medline] [CrossRef]

10. Gore, A. C. 2008. Developmental programming and endocrine disruptor effects on reproductive neuroendocrine systems. Front. Neuroendocrinol. 29: 358-374. [Medline] [CrossRef]

11. Hotchkiss, A. K., Rider, C. V., Blystone, C. R., Wilson, V. S., Harting, P. C., Ankley, G. T., Foster, P. M., Gray, C. L. and Gray, L. E. 2008. Fifteen years after "wingspread"-environmental endocrine disrupters and human and wildlife health: Where we are today and where we need to go. Toxicol. Sci. 105: 235-259. [Medline] [CrossRef]

12. Horii, Y., Dalpatadu, S. L., Soga, T., Ohta, R., Watanabe, G., Taya, K. and Parhar, I. S. 2013. Estrogenic regulation of kiss 1 mRNA variants in Hatano rats. Gen. Comp. Endocrinol. 181: 246-253. [Medline] [CrossRef]

13. Ishii M. N., Matsumoto, K., Matsui H., Seki, N., Matsumoto, H., Ishikawa, K., Hatani, F., Watanabe, G. and Taya, K. 2013. Reduced responsiveness of kisspeptin neurons to estrogenic positive feedback associated with age-relate disappearance of LH surge in middle- age female rats. Gen. Comp. Endocrinol. 193: 121-129. [Medline] [CrossRef]

14. Juraska, J. M., Sisk, C. L. and Doncarlos, L. L. 2013. Sexual differentiation of the adolescent rodent brain: Hormonal influences and developmental mechanisms. Horm. Behav. 64: 203-210. [Medline] [CrossRef]

15. Kauffman, A. S., Gottsch, M. L., Roa, Byquist, A. C., Crown, A. and Clifton, D. K. 2007. Sexual differentiation of kiss 1 gene expression in the brain of the rat. Endocrinology 148: 1774-1783. [Medline] [CrossRef]

16. Li, X. F., Kinsey-Jones, J. S., Cheng, Y., Konx, A. M. I., Lin, Y. and Petrou, N. A. 2009. Kisspeptin signalling in the hypothalamic arcuate nucleus regulates $\mathrm{GnRH}$ pulse generator frequency in the rat. PLOS ONE 4. [Medline] [CrossRef]

17. Maeda, K., Ohkura, S., Uenoyama, Y., Wakabayashi, Y., Oka, Y., Tsukamura, H. and Okamura, H. 2010. Neurobiological mechanisms underlying GnRH pulse generation by the hypothalamus.
Brain Res. 1364: 103-115. [Medline] [CrossRef]

18. Matt, D. W., Glison, M. P., Sales, T. E., Krieg, R. J., Kerbeshian, M. C., Veldhuis, D. and Evans, W. S. 1998. Characterization of attenuated proestrous luteinizing hormone surges in middle-aged rats by deconvolution analysis. Biol. Reprod. 59: 1477-1482. [Medline] [CrossRef]

19. Mayer, C., Martinez, M. A., Dubois, S. L., Wolfe, A., Radovick, S., Boehm, U. and Levine, J. E. 2010. Timing and completion of puberty in female mice depend on estrogen receptor $\alpha$-signaling in kisspeptin neurons. Proc. Natl. Acad. Sci. U.S.A. 107: 2269322698. [Medline] [CrossRef]

20. De Mees, C., Laes, J. F., Bakker, J., Smitz, J., Hennuy, B. and Vooren, P. V. 2006. Alpha-fetoprotein controls female fertility and prenatal development of the gonadotropin-releasing hormone pathway through an antiestrogenic action. Mol. Cell. Biol. 26: 2012-2018. [Medline] [CrossRef]

21. Mueller, S. O. and Korach, K. S. 2001. Estrogen receptors and endocrine diseases: lessons from estrogen receptor knockout mice. Curr. Opin. Pharmacol. 1: 613-619. [Medline] [CrossRef]

22. Nozawa, K., Nagaoka, K., Zhang, H., Usuda, K., Okazaki, S., Taya, K. and Watanabe, G. 2014. Neonatal exposure to $17 \alpha$-ethynyl estradiol affect ovarian gene expression and causes reproductive dysfunction in female rats. Reprod. Toxicol. (in press). [CrossRef]

23. Navarro, V. M., Castellano, J. M., Fernandez-Fernandez, R., Tovar, S., Roa, J., Mayen, A., Barreiro, M. L., Casanueva, F. F., Aguilar, E., Dieguez, C., Pinilla, L. and Tena-Sempere, M. 2005. Effects of KISS-1 peptide, the natural ligand of GPR54, on follicle-stimulating hormone secretion in the rat. Endocrinology 146: 1689-1697. [Medline] [CrossRef]

24. Ohta, R., Ohmukai, H., Marumo, H., Shindo, T., Nagata, T. and Ono, H. 2012. Delayed reproductive dysfunction in female rats induced by early life exposure to low- dose diethylstilbestrol. Reprod. Toxicol. 34: 323-330. [Medline] [CrossRef]

25. Okamura, H., Yamamura, T. and Wakabayashi, Y. 2013. Kisspeptin as a master player in the central control of reproduction in mammals: An overview of kisspeptin research in domestic animals. Anim. Sci. J. 84: 369-381. [Medline] [CrossRef]

26. Overgaard, A., Holst, K., Mandrup, K. R., Boberg, J., Christiansen, S., Jacobsen, P. R., Hass, U. and Mikkelsen, J. D. 2013. The effect of perinatal exposure to ethinyl oestradiol or a mixture of endocrine disrupting pesticides on kisspeptin neurons in the rat hypothalamus. Neurotoxicology 37: 154-162. [Medline] [CrossRef]

27. Pinilla, L., Aguilar, E., Dieguez, C., Millar, R. P. and Sepere, T. 2012. Kisspeptins and reproduction: physiological roles and regulatory mechanisms. Physiol. Rev. 92: 1235-1316. [Medline] [CrossRef]

28. Smith, J. T., Cunningham, M. J., Rissman, E. F., Clifton, D. K. and Steiner, R. A. 2005. Regulation of kiss 1 gene expression in the brain of the female mouse. Endocrinology 146: 3686-3692. [Medline] [CrossRef]

29. Zhang, J., Yang, L., Lin, N., Pan, X., Zhu, Y. and Chen, X. 2014. Aging- related changes in the RP3V kisspeptin neurons predate the reduced activation of GnRH neurons during the early reproductive decline in female mice. Neurobiol. Aging 35: 655-668. [Medline] [CrossRef] 